"مجله علوم زراعى ايران"

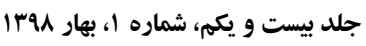

مقاله يُوهشى

اثر ير ايمينك بذر و محلوليّاشى اكسين و سيتوكينين بر رشد و عملكرد دانه كندم در شرايط اقليمى اهواز (Triticum aestivum L.)

Effect of seed priming and application of cytokinin and auxin on growth and grain yield of wheat (Triticum aestivum L.) under Ahvaz climatic conditions

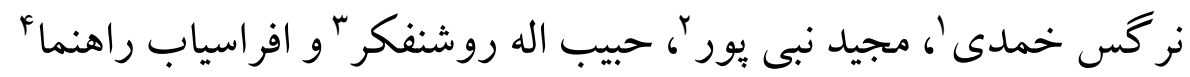

جكيده

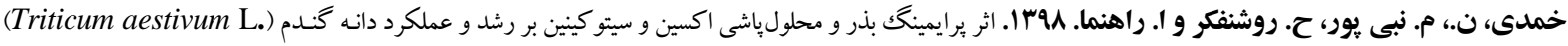
در شرايط اهواز. مجله علوم زراعى ايران. آب(1): عـ-اسب.

به منظور ارزيابى اثر ير ايمينك بذر و محلول ياشى اكسين و سيتوكينين بر عملكرد دانه عندم رقم جمران، آزمايشـى بـه صـورت

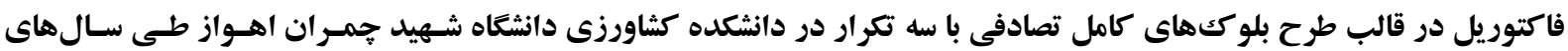

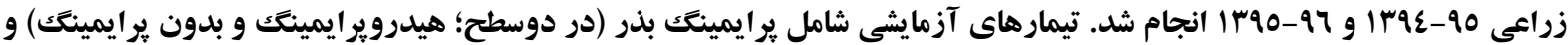

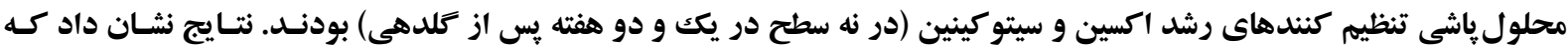

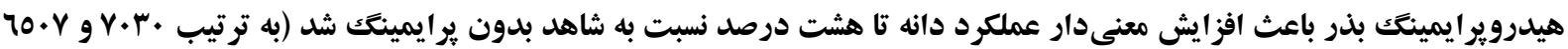
كيلو زرم در هكتار). محلول ياشى اكسين و سيتوكينين بر فتوسنتز و يروتئينهاى محلول بركى يرجم اثر مثبت داشت. بعـلاوه تعـداد

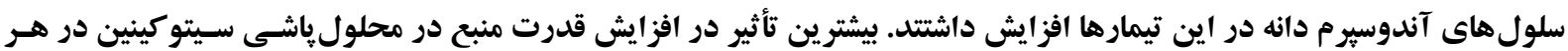

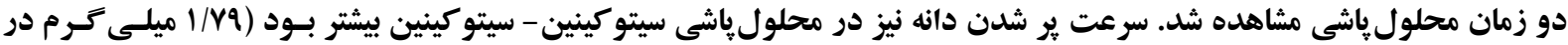

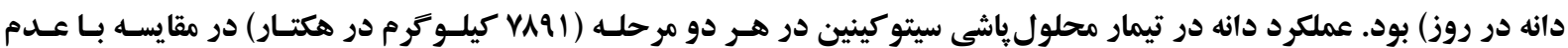
مدحلولياشى، Y/عץ درصد بيشتر بود. نتايج اين آزمايش نشان داد كه يرايمينك بذر باعث افزايش تعداد سنبلهها در واحد سطح شـد. محلول ياشى اكسين و سيتو كينين نيز با افزايش قدرت منبع و مخزن، مى توانند باعث افزايش عملكرد دانه كندم شوند.

وازههاى كليدى: ير شدن دانه، تنظيم كنندههاى رشد، سلول هاى آندوسيرم، گندم و هيدروير ايمينگك.

اين مقاله مستخرج پيايان نامه دكترى نكارنده اول مىباشد.

تاريخ دريافت: F/F

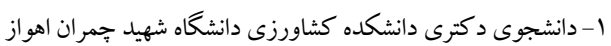

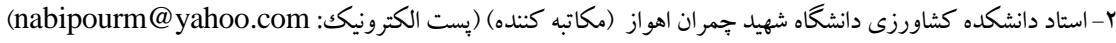

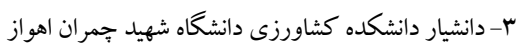

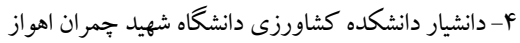


سرعت و درصد جو انهزنى ارقام ديـم در هـر سـه منطقـهـ

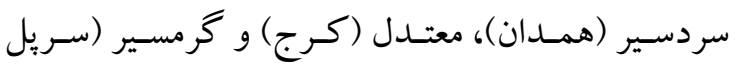
ذهـاب) و رقـم آبـى الونسـ در همـــان در هـر دو زمـان

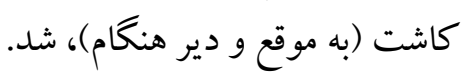

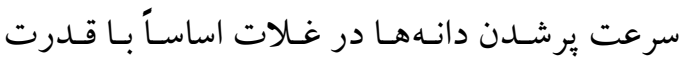

مخزن فيز يولوزيكك تعيين مىشود (Yang et al., 2003).

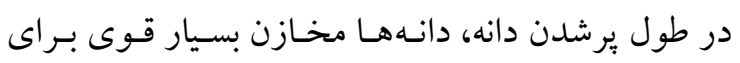

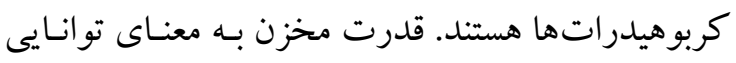

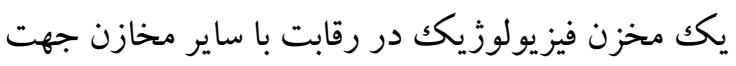

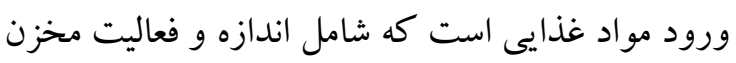

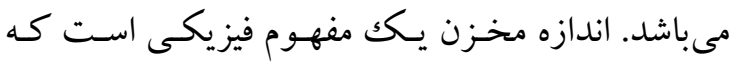

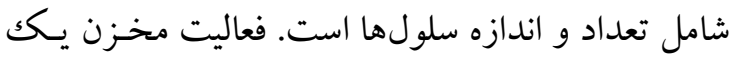

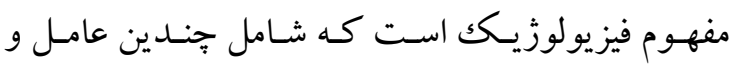

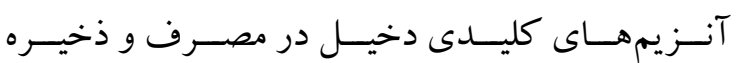
كربوهيـدراتهـا اسـت (Brenner and Cheikh, 1995).

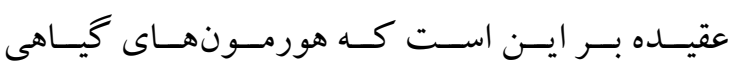

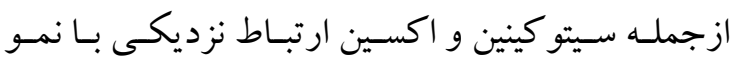

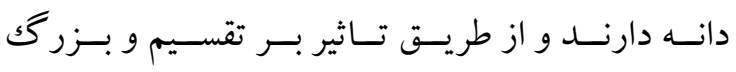

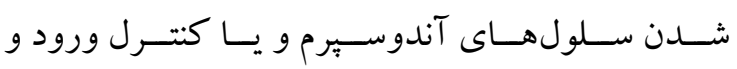

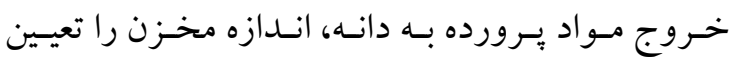

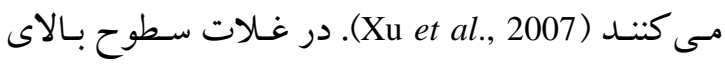

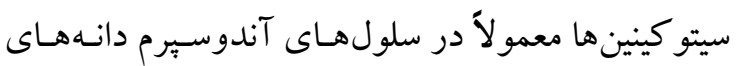
در حال نمو يافت مى شود كه ممكن است بـراى تقسيميم سلولى در طول مر حله اوليه شكل گيرى دانه مـورد نيـاز

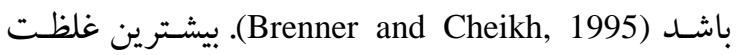

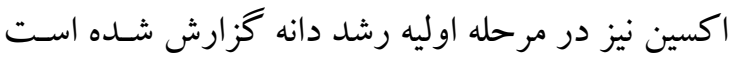

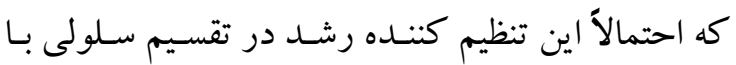
سيتو كينين، به صورت همسازى عمل مى كند و بنـابراين

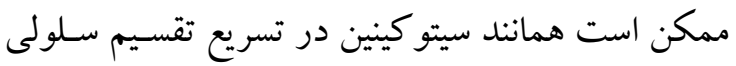

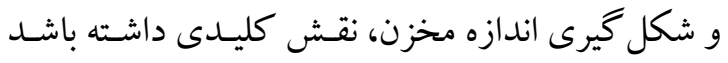
(Saeidi et al., 2006; Wingler et al., 1998) شــده اسـت كـه سـيتو كينين بـه صـورت مسـتقيم بـر شاخص هاى فتوسنتى مانند كلروفيل و سـنتز يـروتئين و

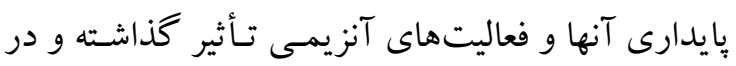

\section{مقلمه}

يكىى از عوامـل افـزايش عملكـــد در واحـد سـطح، افـزايش درصسد و سـرعت جوانسهزنى بــرها و اسـتقرار

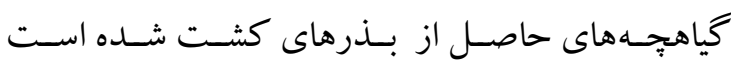

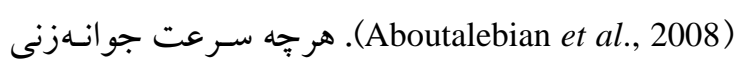
و درصـد بــرهاى جوانـه زده در مزرعـه بيشـتر باشـد،

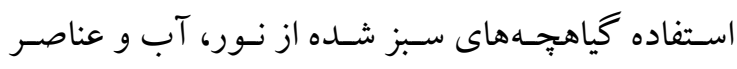

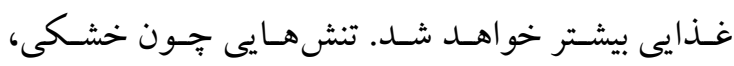

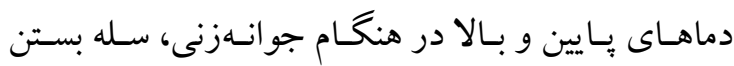
خاكك، زمان كشت نامناسب، آمـاده نبـودن كـافى بسـتر بــذر وغيــره ازجملــه عـــواملى هســتند كــه اسـتقر ار

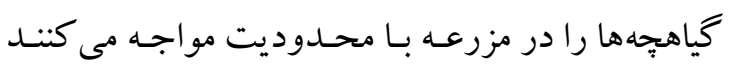
(Farooq et al., 2008; McDonald, 2000) نظرى كيفيت بـذر بـه طـور مسـتقيم و يـا غير مستقيم بـر عملكرد گياهان زراعى اثر مى گَذارد. اثـر غيـر مسـتقيم شامل درصد و زمان از كاشت تا سبز شدن (سرعت سبز

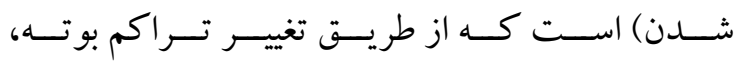
آرايش فضايى و بقاى آنها، بر عملكـرد اثر مسى كـذارد

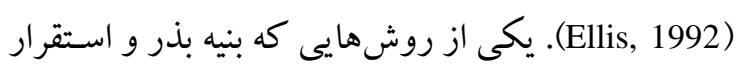

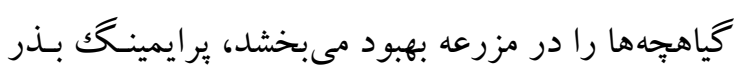
است (McDonald, 2000). (Abdolrahmani et al., عبـدالرحمنى و همكـاران

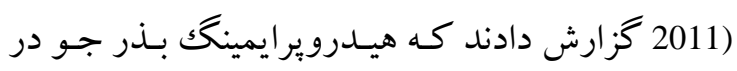
شرايط ديم، باعث افزايش توليـد مـاده خشـك كيـاه در

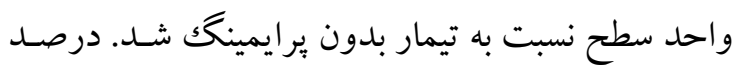
يوشش سبز زمين در مرحله كلدهى و سرعت رشد كياه نيز در ايسن تيمـار بيشـتر بـود. در آزمـايش ايشـان بهبـود عملكرد دانه در اثر هيدرويرايمينگ به استفاده بهينـه از

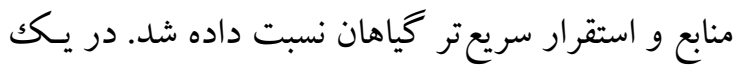
آزمايش كز ارش شد كه برايمينگك بـــر باعـث افـزايش عملكرد كاه و دانه برنج در روش خشكه كـارى (كشت ارت مستقيم بــرر) شــ (Rehman et al., 2011). ابوطالبيـان و همكـاران (Aboutalebian et al., 2008) كَز ارش دادنــ كه هيدروير ايمينگك بـذر گنـدم بـا آب، باعـث افـزايش 
افت عملكرد ناشـى از تـأخير در كاشـت را تـا انـدازهاى

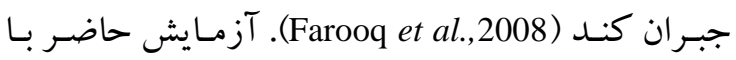
هدف ارزيابى اثر برايمينگك بذر و محلول ياشسى اكسين

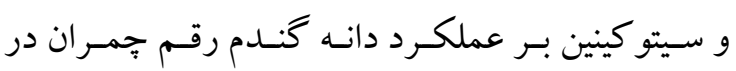
شرايط اقليمى اهواز انجام شد.

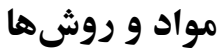

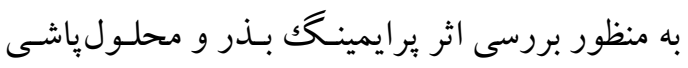

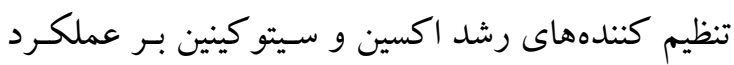

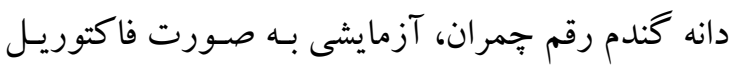
در قالب طرح بلوكك هاى كامل تصادفى با سه تكرار در

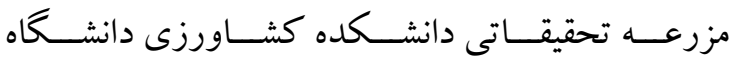

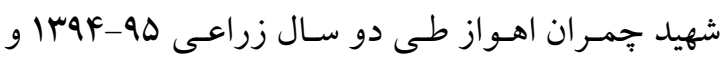

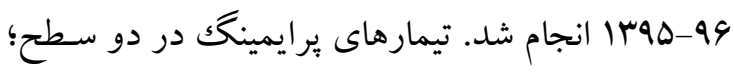

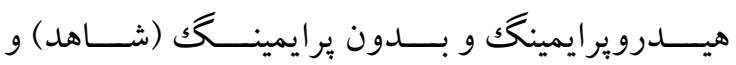

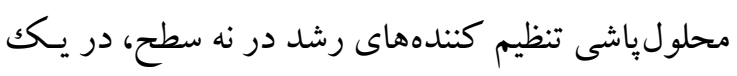

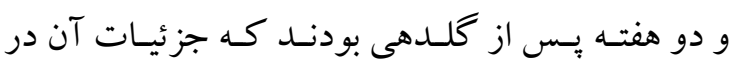

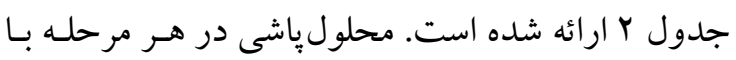
غلظت •ه ميكرومهولار (Ghorbani Javid et al., 2011) اكسين (Indole 3- Acetic Acid free acid, Sigma) و سيتو كينين (Kinetin, Sigma) انجـام شـــ از تييسول بـا نسبت ه/ • درصد حجمى به عنوان مويـان استفاده شـد.

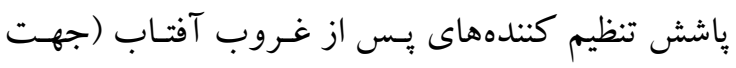

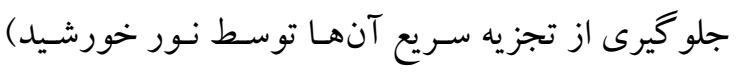

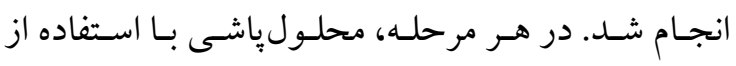

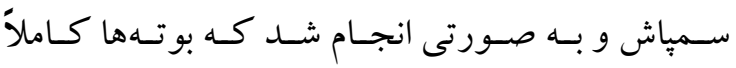

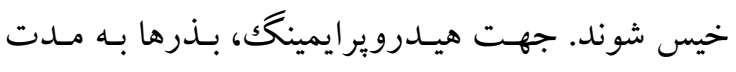
هشت ساعت (بـر اسـاس نتـايج آزمـايش مقــدماتى) در

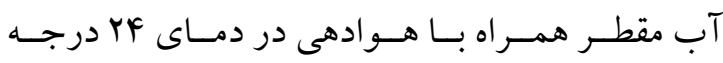

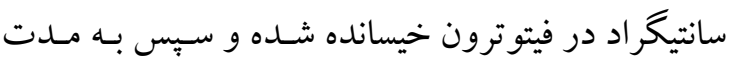

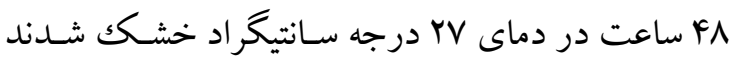

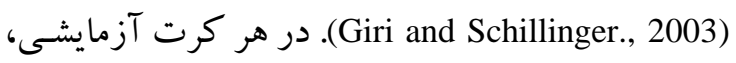

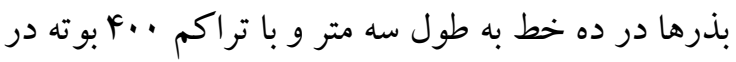

نهايـت سـرعت و يايــارى فتوسـنتز در واحسـ زمـان را

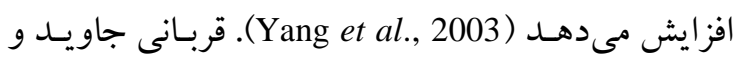
همكاران (Ghorbani Javid et al., 2011) اثر محلـول

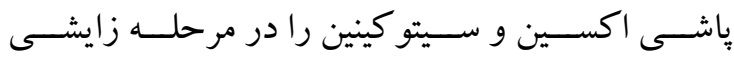

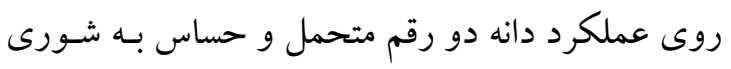

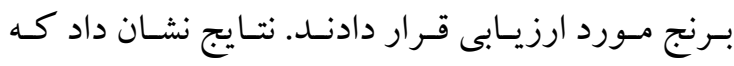

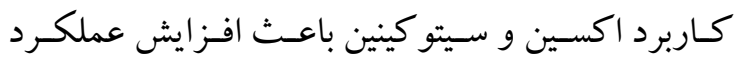

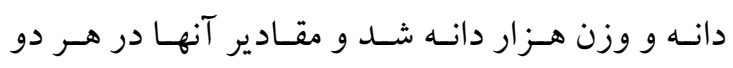

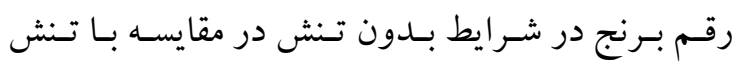
شـورى افزايش يافـت. در آزمـايش كويتـا و همكـاران (Gupta et al., 2003) (بنزيل آدنين) روى دانههاى سه زنوتيب كندم (از لحاظ

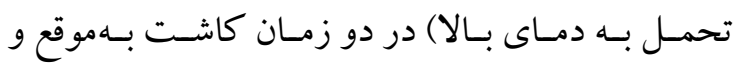

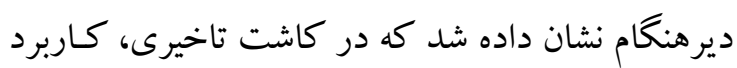

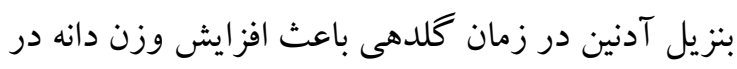

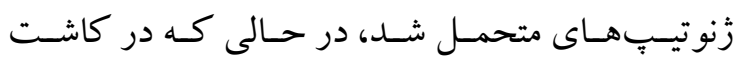

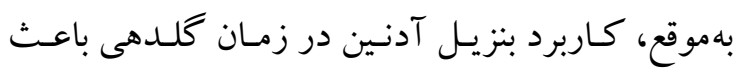
افزايش وزن دانه در هر سه زُنوتيب گرديد.

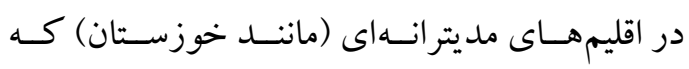

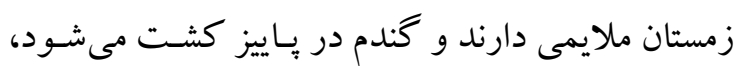

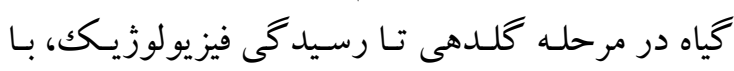

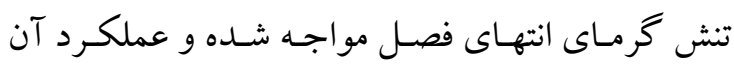

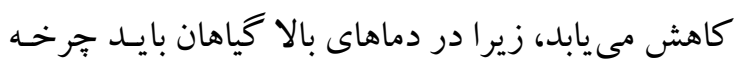

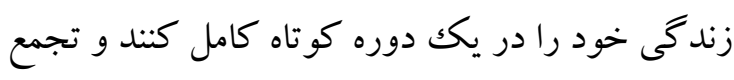
نشاسته در آنها زودتر بايان مى يابد (Khan et al., 2010).

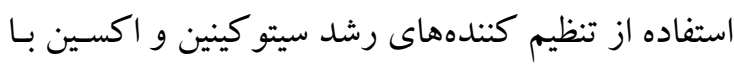

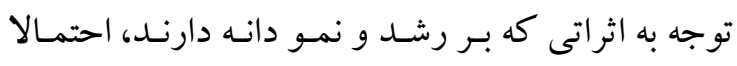

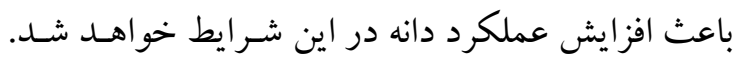

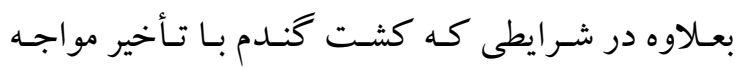

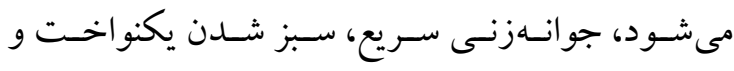

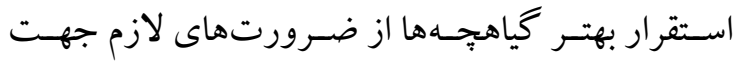

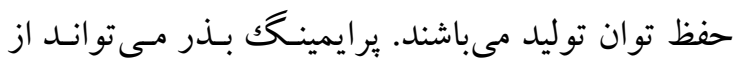

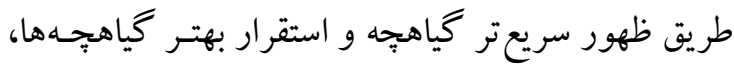




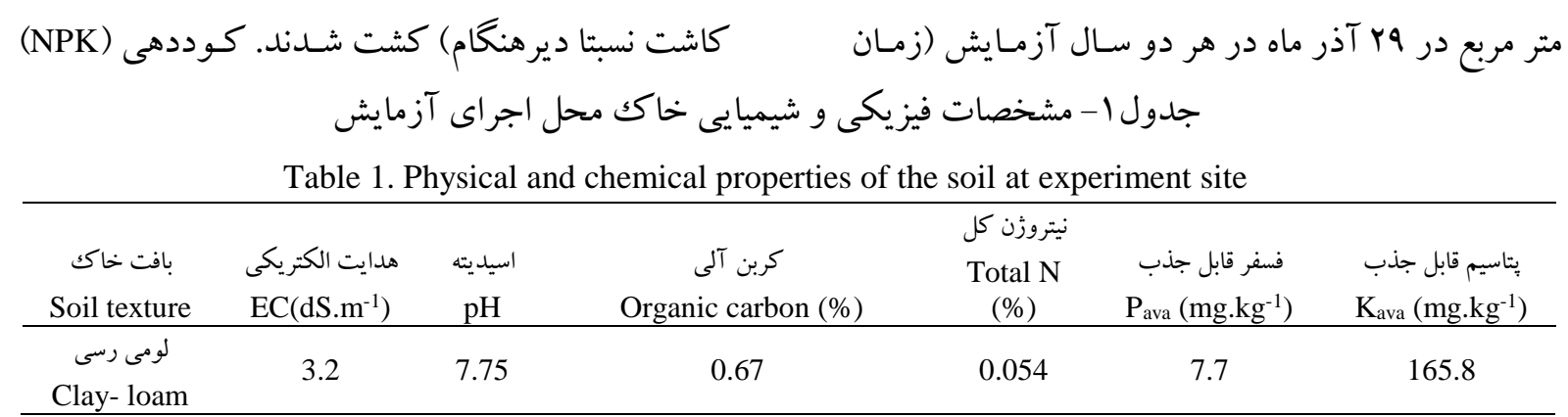

و بر اساس تناسب مشخص شد. تعداد دانه در سـنبله نيـز

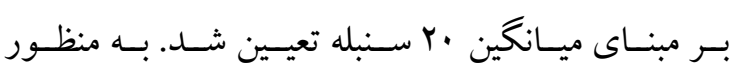

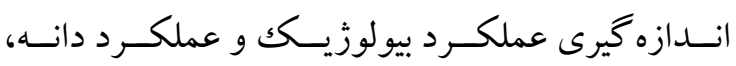

دو رديـف اول و انتهـا و نسيممتـر از ابتــدا و انتهـاى بقيسه

رديفهـا بـهنهنوان حاشـيه حسذف و محصـول از سـطح

باقيمانده (1/4 متر مربع) برداشت شد.
بر مبناى نتايج آزمون خاكك و بـر اسـاس • ه كيلـو كرم در هكتار نيتروزن خالص (در دو مرحله؛ زمان كاشتت و

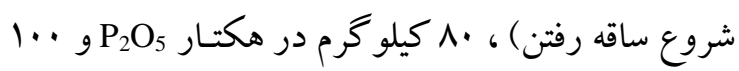
كيلو كرم در هكتار K2O (در زمان كاشـت ) انجـام شـد. تعداد سنبله در متر مربع با شمارش تعداد سنبلههاى واقع در دو نمونه تصادفى از كوادرات • له سانتىمتر مربعى مريح

جدول Y- زمان بندى محلول ياشى تنظيم كنندهاى رشد

Table 2. Timing of application of growth regulators

\begin{tabular}{|c|c|c|}
\hline $\begin{array}{l}\text { تيمارهاى محلولياشى } \\
\text { Growth regulator application treatments }\end{array}$ & 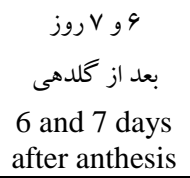 & 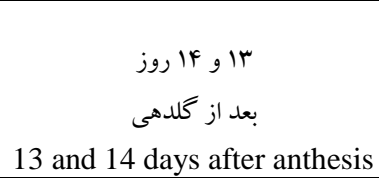 \\
\hline $\mathrm{T} 1$ & Water & Water \\
\hline $\mathrm{T} 2$ & IAA & Water \\
\hline $\mathrm{T} 3$ & Water & IAA \\
\hline $\mathrm{T} 4$ & IAA & IAA \\
\hline $\mathrm{T} 5$ & CK & Water \\
\hline T6 & Water & CK \\
\hline $\mathrm{T} 7$ & $\mathrm{CK}$ & CK \\
\hline $\mathrm{T} 8$ & IAA & CK \\
\hline T9 & $\mathrm{CK}$ & IAA \\
\hline
\end{tabular}

يـكك ظهــر بطــور همزمــان در مزرعــه انجــام شــد.

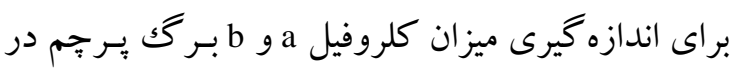

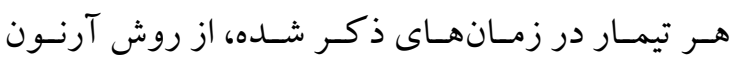

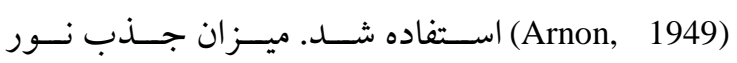
توسط عصاره با استفاده از دســاه اسـيكتروفتومتر و در

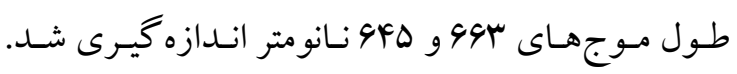

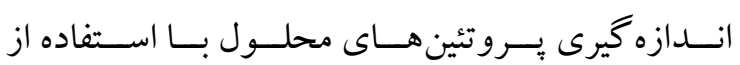

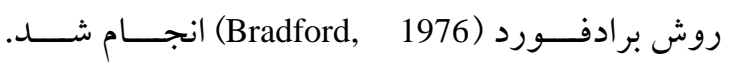
ميـز ان جـــب نــور محلــول بــا اسـتفاده از دســــاه
در زمانهـاى اY و Y Y روز بعـد از كلـدهى، از هـر

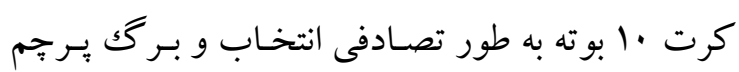

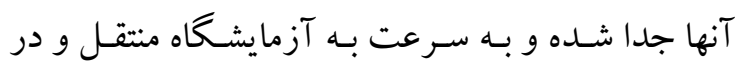

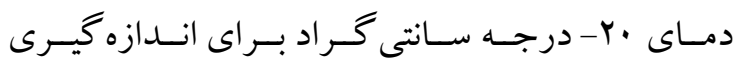
رنخيزههاى فتوسنتزى و بروتئين هـاى محلـول نخهـدارى شدند. سرعت فتوسنتز با استفاده از دستخاه انـدازه گيرى وني فتوسـنتز (LCA-4, ADS, UK) و هـدايت روزنسهاى بـا اسـتفاده از دستّگاه يـورومتر (Prometer, ELE, UK) در

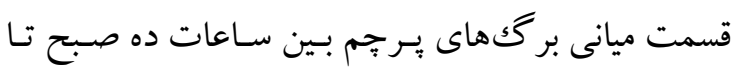


آزمـايش باشـــ (جــول F). در آزمـايش حاكومـات و

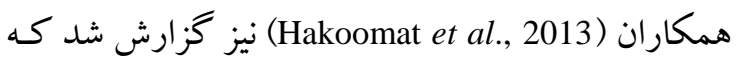

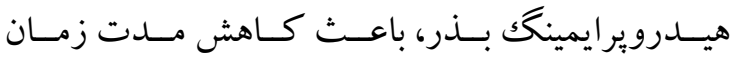

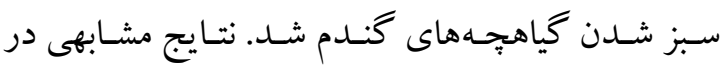

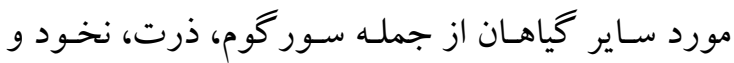

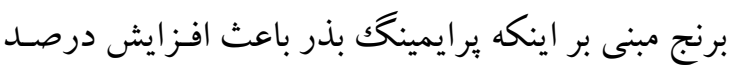

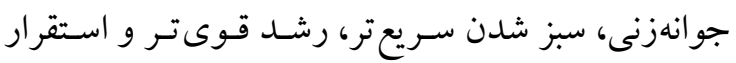

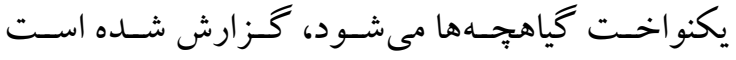

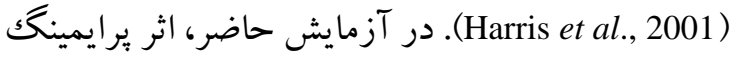

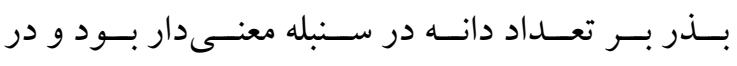

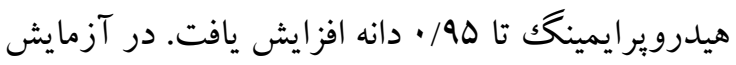

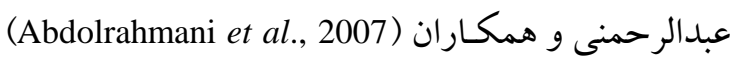

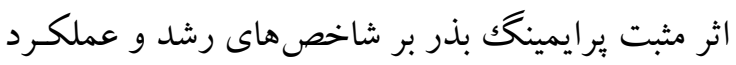

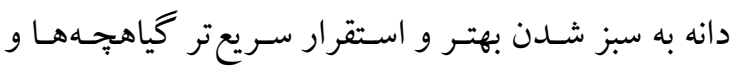

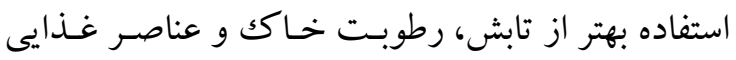

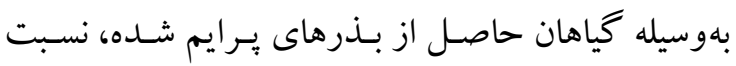

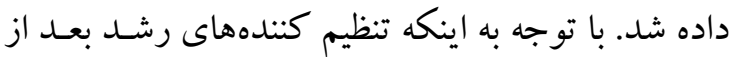

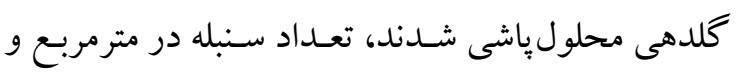

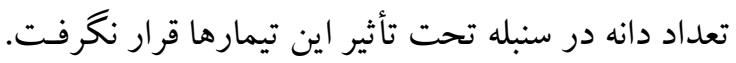

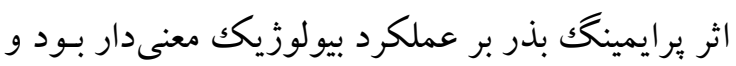

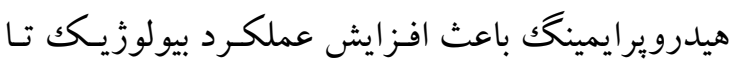

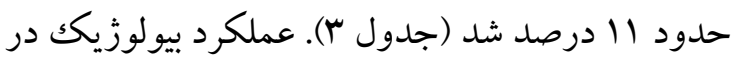
سال دوم آزمايش به صـورت معنسى دارى بيشـتر از سـال

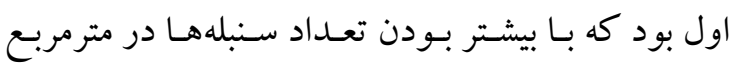
هماهنخى داشت (جدول r). نتايج تجزيه واريانس نشان داد كـه اثر محلولي ياشى دهى

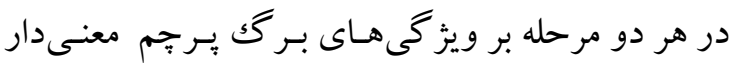

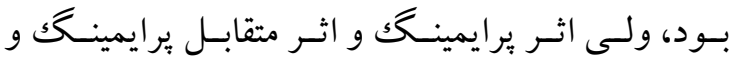

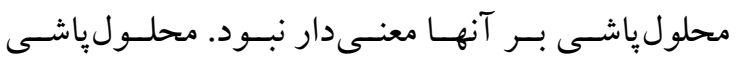

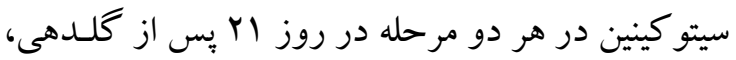

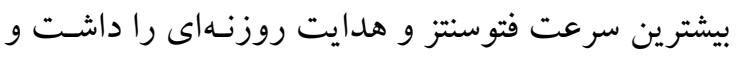

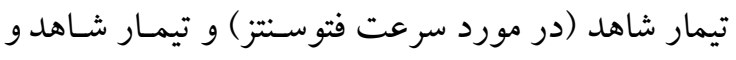

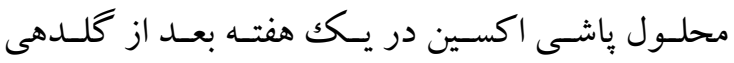

اسبكتروفتومتر در طـول مـوج هQ هانـانومتر انسازه گيرى

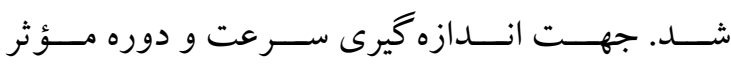

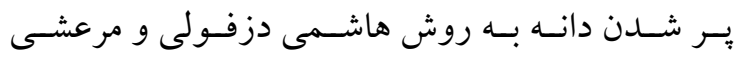
(Hashemi Dezfouli And Marashi, 1995)

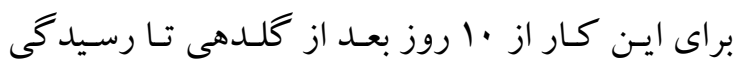

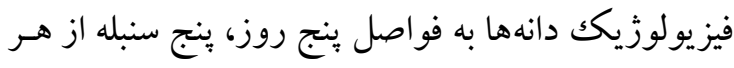

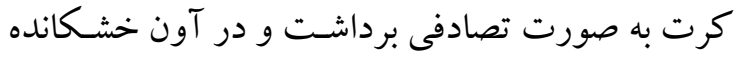

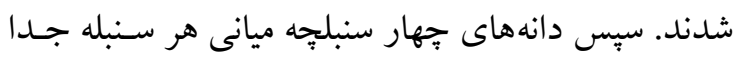

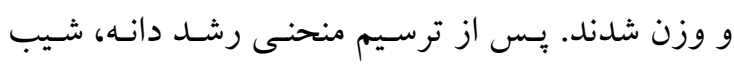

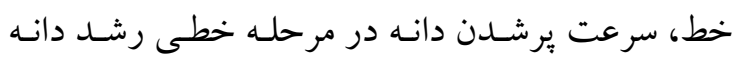

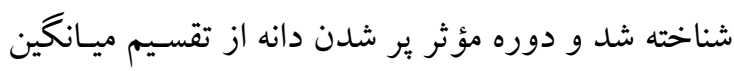

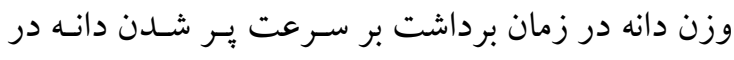

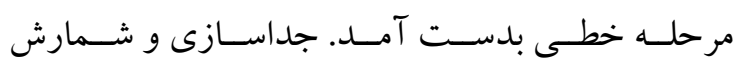

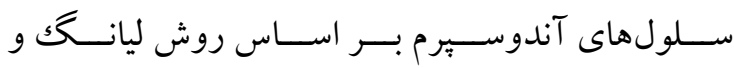

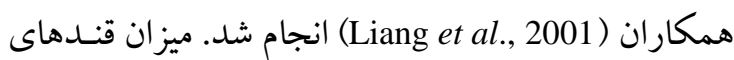
محلـول دانسه بـا اسـتفاده از روش دابيـوس و همكــاران (Dubios et al., 1956)

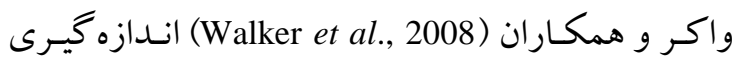
شد. تجزيههاى آمارى با استفاده از نرم افزار SAS نسخه

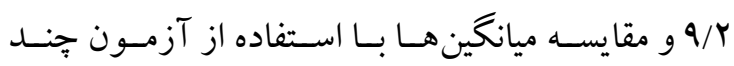
دامنهاى دانكن در سطح احتمال بِنج درصد انجام شد.

\section{نتايج و بحث}

نتايج تجزيه واريانس نشان داد كه برايمينك بذر اثر

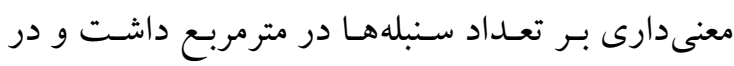

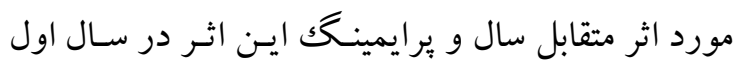

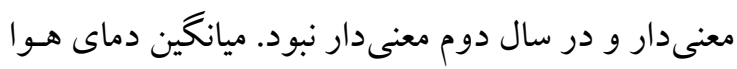

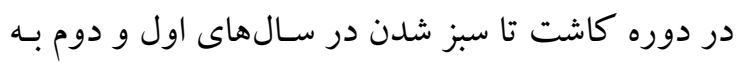

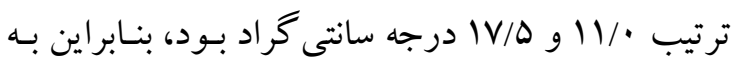

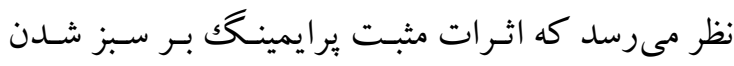
كياهجهها، در شـر ايط دمـايى نامناسـب سـال اول بيشـتر بوده است كه نتيجه اين موضوع مى تواند تأثير بيشـتر آن

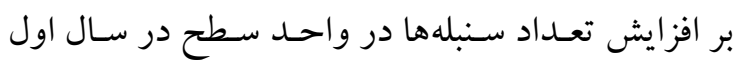


كلدهى نيز محلـولياشىى سـيتو كينين در هـر دو مرحله.

(در مورد هدايت روزنـهاى)، بـدون اخـتلاف معنسىدار،

بيشترين سرعت فتوسنتز و هدايت روزنسهاى را داشـت و

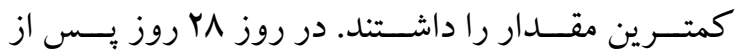

جدول ب- مقايسه ميانگين تعداد دانه در سنبله، عملكرد دانه و عملكرد بيولوزيك كندم در تيمارهاى سال و ير ايمينگك بذر

Table 3. Mean comparison of No. of grain.spike ${ }^{-1}$, grain yield and biological yield of wheat

in year and seed priming treatments

\begin{tabular}{|c|c|c|c|c|}
\hline Year & سال & $\begin{array}{c}\text { دانه در سنبله } \\
\text { No. Grain.spike } 11\end{array}$ & $\begin{array}{c}\text { عملكرد دانه } \\
\text { Grain yield }\left(\mathrm{kg}^{2} \mathrm{ha}^{-1}\right)\end{array}$ & 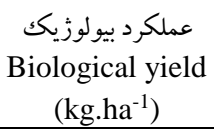 \\
\hline $2015-2016$ & $\mid r q F-1 T q \Delta$ & $34.2 \mathrm{a}$ & $6497 b$ & $13688 b$ \\
\hline 2016-2017 & $1 \% q \Delta-1 r q 9$ & $34.3 \mathrm{a}$ & $7040 \mathrm{a}$ & $15275 \mathrm{a}$ \\
\hline Seed priming & ير ايمينك بذر & & & \\
\hline Hydropriming & هيدرويرايمينك & $34.8 \mathrm{a}$ & $7030 a$ & $15272 \mathrm{a}$ \\
\hline Without priming (control) & بدون بر ايمينك & $33.8 b$ & $6507 \mathrm{~b}$ & $13691 b$ \\
\hline
\end{tabular}

در هر ستون ميانكين هايى كه داراى حروف مشترك هستند، بر اساس آزمون جند دامنهاى دانكن در سطح احتمال ينج درصد تفاوت معنى دارى ندارند Means in each column followed by similar letter(s) are not significantly different at 5\% probability level, using Duncan's Multiple Range Test

$$
\text { جدول F- مقايسه ميانكين تعداد سنبله در مترمربع گندم در اثر متقابل تيمارهاى سال و ير ايمينگك بذر }
$$

Table 4. Mean comparison of No. of spike. $\mathrm{m}^{-2}$ of wheat in year $\times$ seed priming treatments

\begin{tabular}{|c|c|c|c|}
\hline سال Year & \multicolumn{2}{|l|}{$\begin{array}{c}\text { يرايمينگ بذر } \\
\text { Seed priming }\end{array}$} & $\begin{array}{l}\text { سنبله در مترمربع.mike.m } \\
\text { Spike }\end{array}$ \\
\hline $\mid r q F-1 \% q \Delta$ & Hydropriming & هيدرويرايمينك & $485.0 \mathrm{~b}$ \\
\hline $2015-2016$ & Without priming (control) & بدون برايمينك & $428.0 \mathrm{c}$ \\
\hline $1 r q \Delta-1 r 99$ & Hydropriming & هيدروير ايمينك & $503.2 \mathrm{a}$ \\
\hline 2016-2017 & Without priming (control) & بدون برايمينك & $490.0 \mathrm{ab}$ \\
\hline
\end{tabular}

در هر ستون ميانگينهايى كه داراى حروف مشترك هستند، بر اساس آزمون جند دامنهاى دانكن در سطح احتمال ينج درصد تفاوت معنى دارى ندارند

Means in each column followed by similar letter(s) are not significantly different at 5\% probability level, using Duncan's Multiple Range Test

$$
\begin{aligned}
& \text { فتوسنتزى در اثر مصـرف خـارجى اكسـين نيـز كـزارش } \\
& \text { شــه اسـت (Amal et al., 2009). اكسـينهــا اولـين }
\end{aligned}
$$

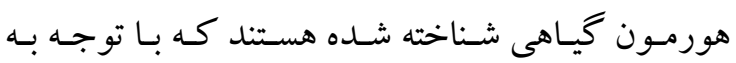

$$
\begin{aligned}
& \text { توانايى در القاى طويل شدن سلول در ساقههـا، برگكهـا } \\
& \text { و افزايش فعاليتهاى فتوسنتزى در كياهان مـورد توجـهـ } \\
& \text { قرار كرفتند (Bajguz and Piotrowska, 2009). }
\end{aligned}
$$

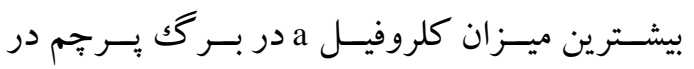

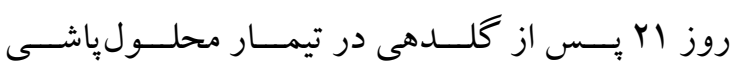

$$
\begin{aligned}
& \text { سـيتو كينين در هـر دو مرحلـه دسـت آمـــ. تيمارهــاى } \\
& \text { محلسول باشسى سـيتو كينين - آب، اكسـين - سـيتو كينين و } \\
& \text { سيتو كينين - اكسين (به ترتيب در زمانهاى يـك هفتـه و }
\end{aligned}
$$

بعـد از آن محلـولياشـى اكسـين در يـك هفتـه بعـد از كلدهى و سيتو كينين در زمان دو هفته بـس از كلـدهى، بيشترين مقدار رادارا بودند (جدول ه). به نظر مسىرســ كه تـأثير محلـولياشسى سـيتو كينين بـر افزايش سـرعت فتوسنتز و هدايت روزنهاى بيشتر از محلولياشى اكسين بوده است. همجنين مشاهده شد كه تداوم اثر سيتو كينين بـر ايسن صـفات بيشـتر از اكسـين بـوده اسـت. سـعيدى سكي

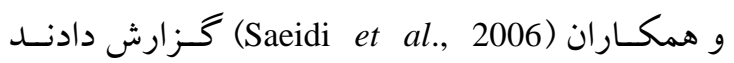
كه محلول ياشى سيتو كينين با افزايش ميزان فتوسـنتز در

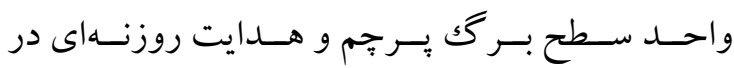

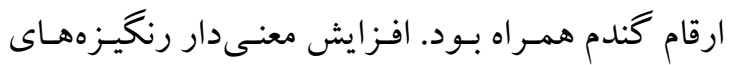


توتـون، بيـان زن ZOG1 (ز آتين كليكوزيـل ترانسـفراز؛ (Havlova et al., 2008) (zeatin o-glucosyltransferase باعث تأخير در بيرى شدند.

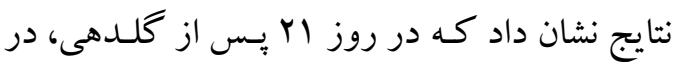
كليه تيمارهاى محلول بياشى محتوى بروتئين هاى محلول

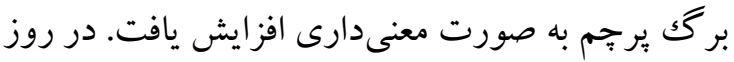

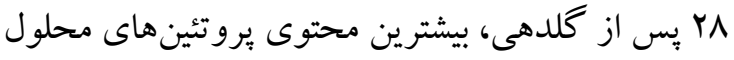

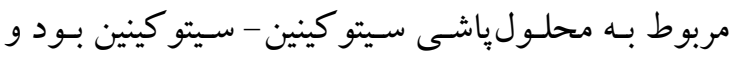

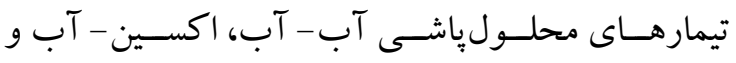

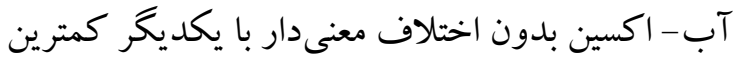

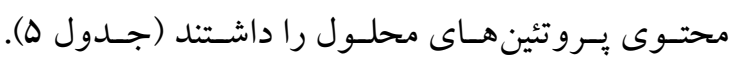

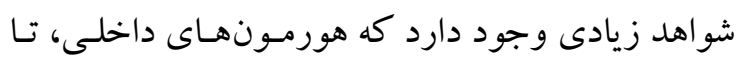

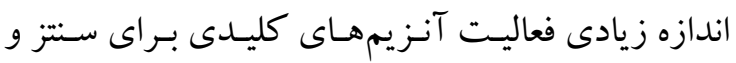
تجمع نشاسته مانند آنزيمهـاى سـاكارز فسـفات سـينتاز، كلو كز بيروفسفوريلاز، فرو كتوز او وبىفسـفاتاز را

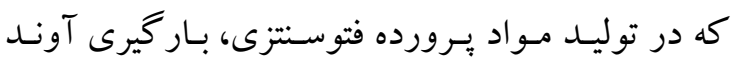
آبكش، انتقال و تسهيم دخيل هستند را تنظيم مس كنـــ

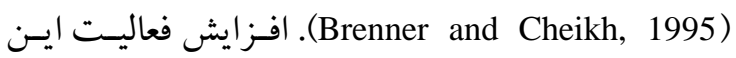

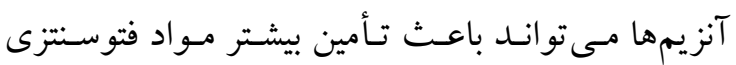

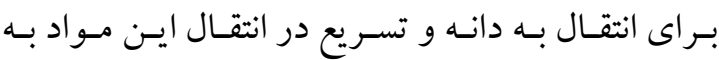

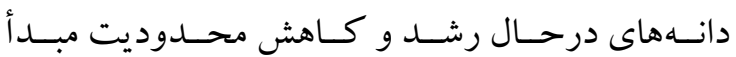
فيزيولوزيكى شود. نتـايج آزمايش وينگلــ و همكـاران نشـان داد كـه سـيتو كينين، (Wingler et al., 1998)

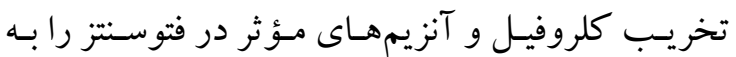
تأخير مى اندازد. اثر محلول ياشى سيتو كينين و اكسين هورمسونياشسى بر خصوصسيات مـتبط بـا دانـه معنسى دار بـود، ولى اثر

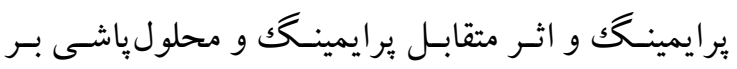
خصوصيات ارزيابى شـده معنسى دار نبـود. نتـايج مقايسـهـ

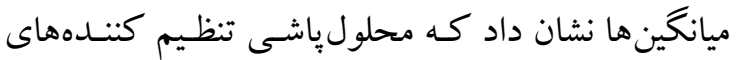

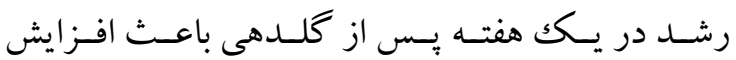

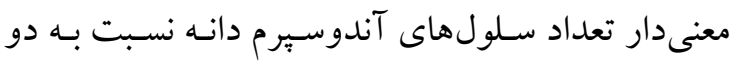

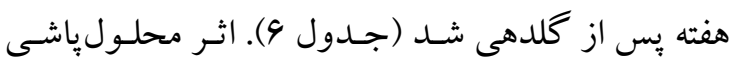

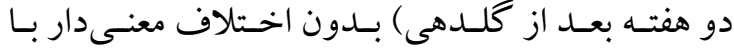
يكديخر، بعد از محلـولياشى سـيتو كينين - سـيتو كينين،

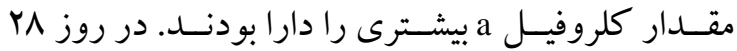

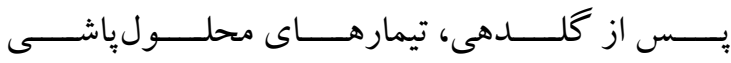
سيتو كينين - سيتو كينين و آب- آب به ترتيب بيشترين و و

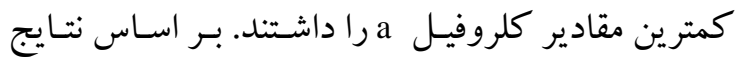

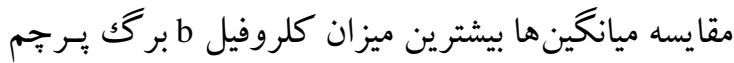

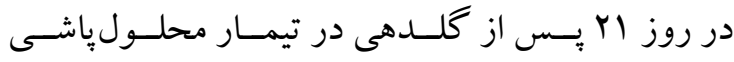

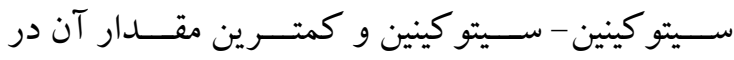

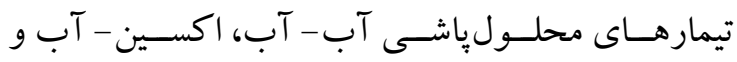
آب- اكسين (بـدون اخستلاف معنسى دار بـا يكســيخر)

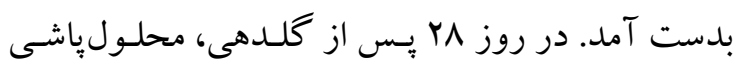

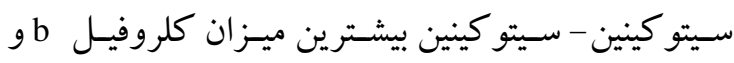

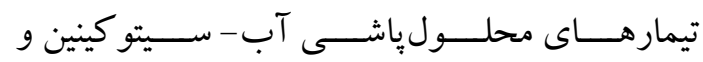

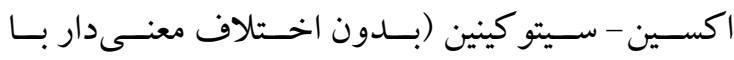

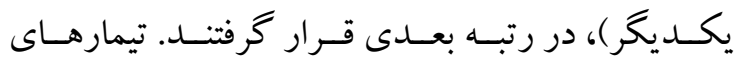

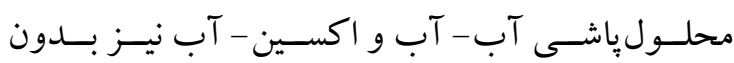

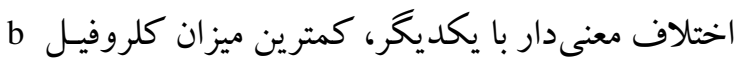

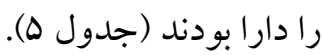

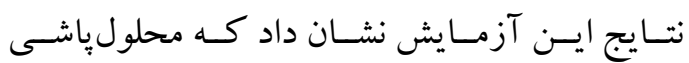

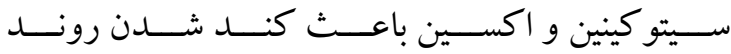

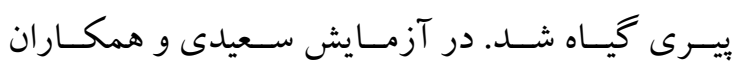
كز ارش شـد كـه محلـولٍياشى (Saeidi et al., 2006) سيتو كينين علاوه بر افزايش نسبى محتواى كلروفيـل a و

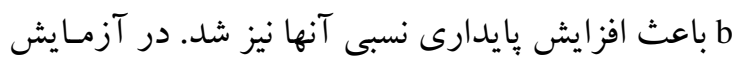

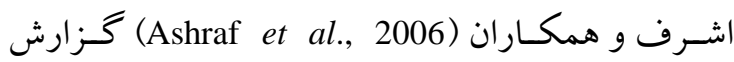

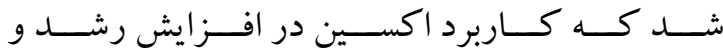

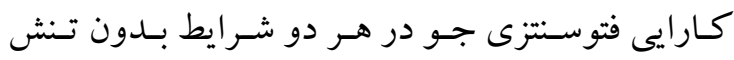

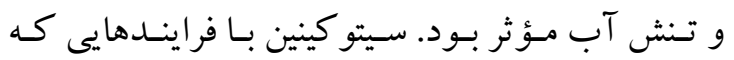

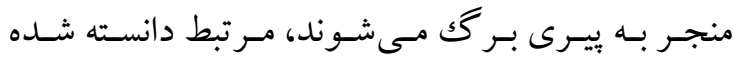

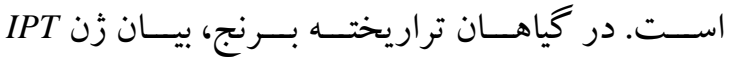

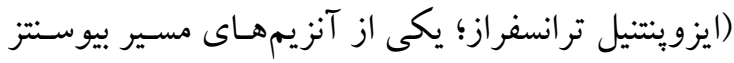

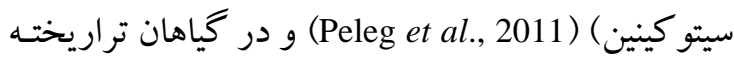


بيشتر بوده اسـت. بـه نظـر مىرسـد كـه محلول ياشـى در

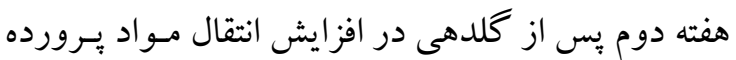

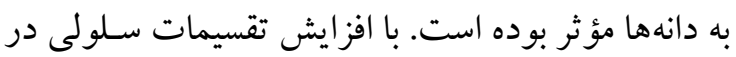

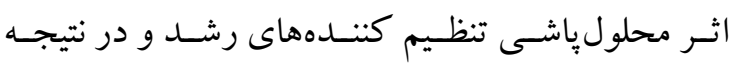

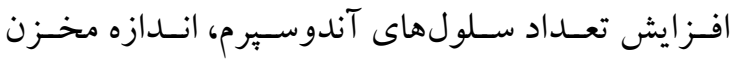

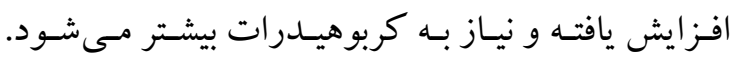

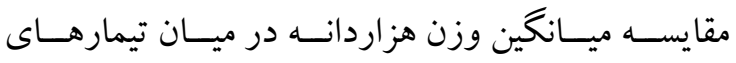

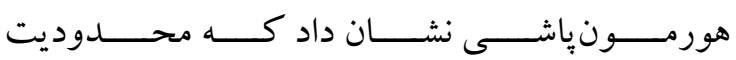

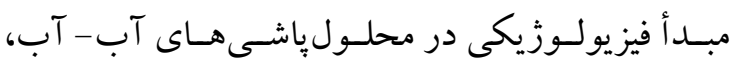
اكسين - آب و سيتو كينين - آب (محلول ياشى به ترتيسب

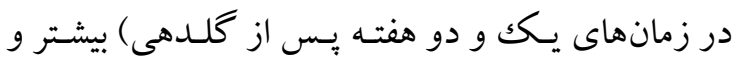

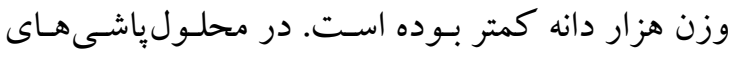

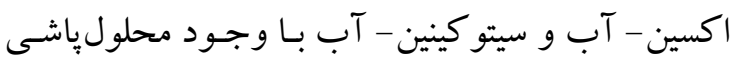
در هفته اول بس از گلدهى، احتمالا محدوديت مبدأ در زمان بر شدن دانه باعـث معنى دار نبـودن اختلاف وزن

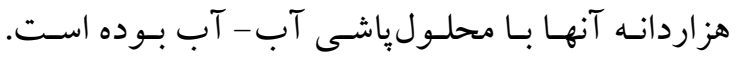
درمورد محتو اى قندهاى محلول و محتوى نشاسته دانـه

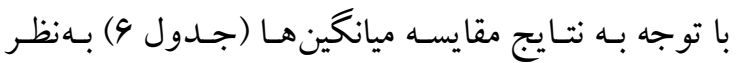
مىرسد كه محلولياشى اكسين و سيتو كينين در هفتـه دوم بس از كلدهى در افز ايش محتـوى نشاستـه دانـه و

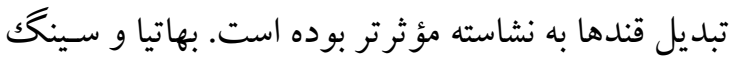
نيسز گَزارش دادنسد كـه (Bhatia and Singh, 2002) مصـرف IAA موجــب افـز ايش محتــواى نشاسـته در

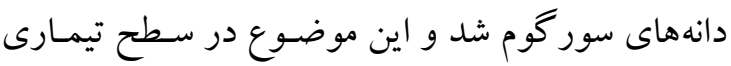

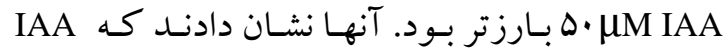
واسطه افزايش در بيوستن C C"ا (قند + نشاسته) به نشاسته كرديد كه نشان دهنده نقش مثبت اين هورمون در تغيير شكل دادن قندها به نشاسته در دانه اسـت. در آزمـايش بلـكَ و همكـاران (Peleg et al., 2011) مقايسـه بسين

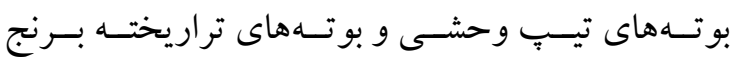

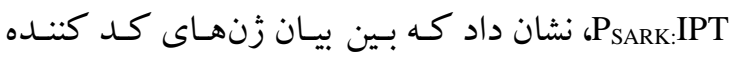
آنزيمهـاى واسـط در بيوسـنتز و هموستازى سـيتو كينين تفـاوت وجسود داشـت. بررسـى اثـر بيـان IPT و ســنتز

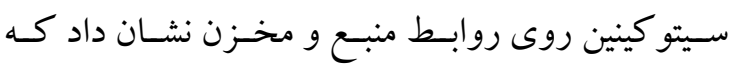

سيتو كينين و اكسين بر تعداد سـلولهاى آندوسـرم دانسه

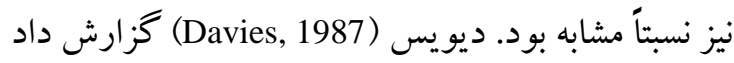
كه اكسين قادر است تقسيم سلولى را همانند سيتو كينين

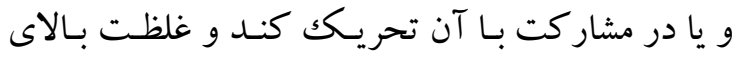
اكسـين در دانسهــا، مسى توانسد باعـث توليسـ بيشـتر

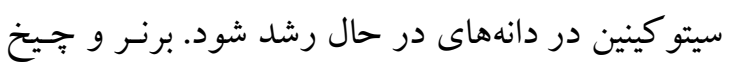
كَزارش دادنـد كـه در (Brenner and Cheikh, 1995) مرحله برشدن دانهها، غلظت اكسين در دانههاى درحال

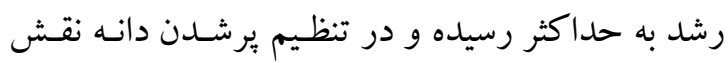

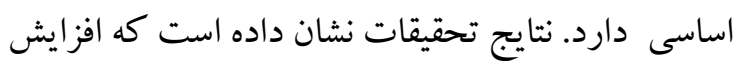

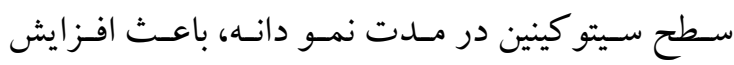

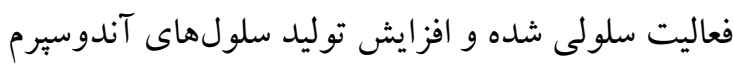

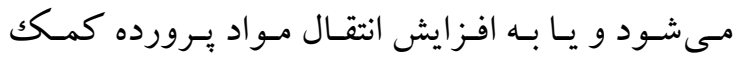

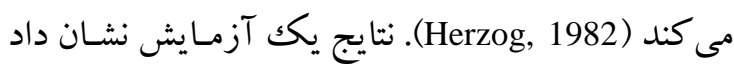

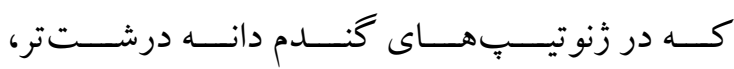
مو اد شبه سيتو كينين بيشترى وجـود داشـت و رشـــ ايـن دانها در اثر مصرف سيتو كينين خارجى افز ايش يافتـ .(Dua and Bhardwaj, 1979) بر اساس نتايج مقايسه ميانخينها به نظر مىرسـد كه.

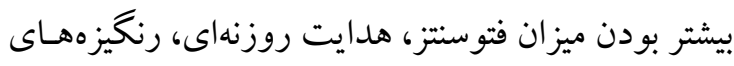

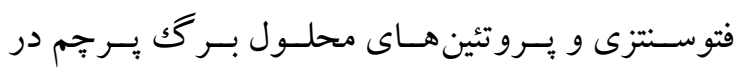

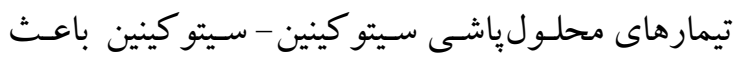

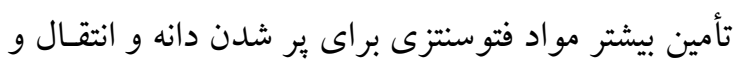

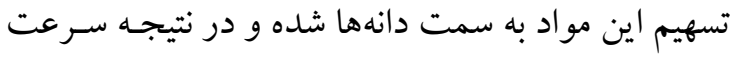

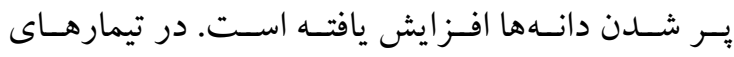

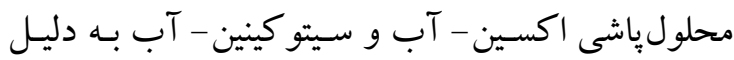

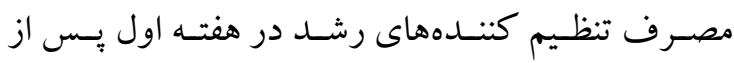

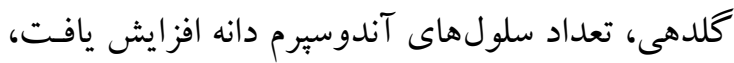

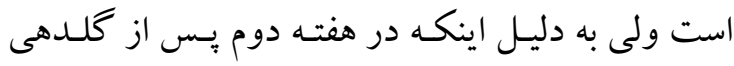

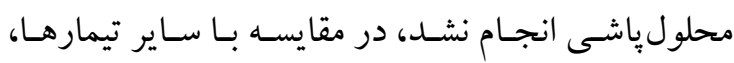

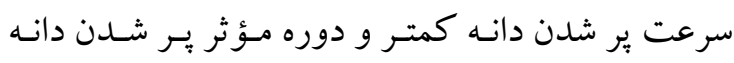
بيشتر بود (جدول 9). نتايج نشان داد كه در تيمارهايى كه در آنها در هـر

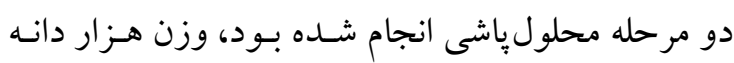




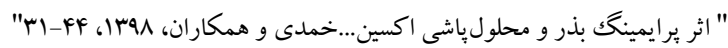

محتواى نشاسته در دانههــاى بدست آمـده از بوتـههاى تراريختهـ بـا آبيـارى مناسـب و تحــت تـنش، نسـبت بـهـ بوته هاى تيب وحشى افزايش معنسىدارى داشـت. نتـايج

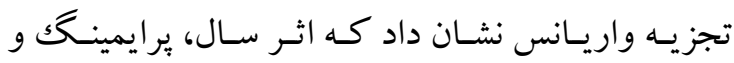

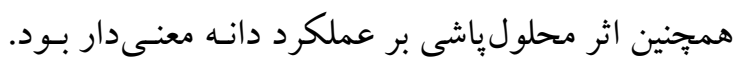

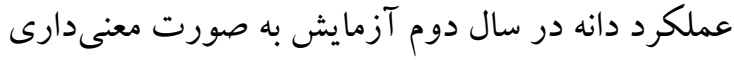




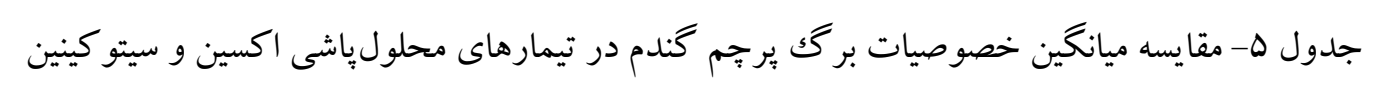

Table 5. Mean comparison of flag leaf characteristics of wheat in auxin and cytokinin application treatments

\begin{tabular}{|c|c|c|c|c|c|c|c|c|c|c|c|c|}
\hline \multicolumn{3}{|c|}{$\begin{array}{c}\text { تيمارهاى محلولياشى } \\
\text { Growth regulator } \\
\text { application treatments }\end{array}$} & \multicolumn{2}{|c|}{$\begin{array}{c}\text { سرعت فتوسنتز } \\
\text { Rate of photosynthesis } \\
\left(\mu \mathrm{mol} . \mathrm{m}^{-1} . \mathrm{s}^{-1}\right)\end{array}$} & \multicolumn{2}{|c|}{$\begin{array}{c}\text { هدايت روزنهاى } \\
\text { Stomatal conductance } \\
\left(\mathrm{mol} \mathrm{CO} 2 . \mathrm{m}^{-1} . \mathrm{s}^{-1}\right)\end{array}$} & \multicolumn{2}{|c|}{$\begin{array}{c}\text { a كلروفيل } \\
\text { Chlorophyll a } \\
\left(\mathrm{mg} \cdot \mathrm{g}^{-1} \mathrm{FW}\right)\end{array}$} & \multicolumn{2}{|c|}{$\begin{array}{c}\text { b كلروفيل } \\
\text { Chlorophyll b } \\
\text { (mg.g-1 FW) }\end{array}$} & \multicolumn{2}{|c|}{$\begin{array}{c}\text { يُروتئن هاى محلول } \\
\text { Soluble proteins } \\
\left(\mathrm{mg} \cdot \mathrm{g}^{-1} \mathrm{FW}\right) \\
\end{array}$} \\
\hline $\mathrm{T}$ & 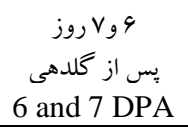 & 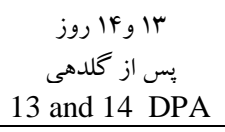 & (21 DPA) & (28 DPA) & (21 DPA) & (28 DPA) & (21 DPA) & (28 DPA) & (21 DPA) & (28 DPA) & (21 DPA) & (28 DPA) \\
\hline $\mathrm{T} 1$ & Water & Water & $19.5 \mathrm{f}$ & $5.69 \mathrm{~g}$ & $0.570 \mathrm{f}$ & $0.120 \mathrm{~h}$ & $1.36 \mathrm{e}$ & $0.45 \mathrm{~h}$ & $0.390 \mathrm{~d}$ & $0.100 \mathrm{f}$ & $9.7 \mathrm{c}$ & $4.97 \mathrm{~d}$ \\
\hline $\mathrm{T} 2$ & IAA & Water & $21.1 \mathrm{e}$ & $6.01 \mathrm{~g}$ & $0.585 \mathrm{ef}$ & $0.130 \mathrm{~g}$ & $1.45 \mathrm{~d}$ & $0.47 \mathrm{~g}$ & $0.400 \mathrm{~d}$ & $0.103 \mathrm{f}$ & $10.3 \mathrm{~b}$ & $5.0 \mathrm{~d}$ \\
\hline $\mathrm{T} 3$ & Water & IAA & $21.2 \mathrm{ed}$ & $7.05 \mathrm{f}$ & $0.600 \mathrm{e}$ & $0.200 \mathrm{f}$ & $1.47 \mathrm{~d}$ & $0.63 \mathrm{f}$ & $0.396 \mathrm{~d}$ & $0.147 \mathrm{e}$ & $10.3 b$ & $5.1 \mathrm{~cd}$ \\
\hline $\mathrm{T} 4$ & IAA & IAA & $22.1 \mathrm{~cd}$ & $7.87 \mathrm{e}$ & $0.665 d$ & $0.250 \mathrm{e}$ & $1.62 \mathrm{c}$ & $0.86 \mathrm{e}$ & $0.577 \mathrm{c}$ & $0.171 \mathrm{~d}$ & $10.4 \mathrm{ab}$ & $5.4 \mathrm{bc}$ \\
\hline T5 & $\mathrm{CK}$ & Water & $22.1 \mathrm{~cd}$ & $7.86 \mathrm{e}$ & $0.670 \mathrm{~d}$ & $0.245 \mathrm{e}$ & $1.66 \mathrm{bc}$ & $0.86 \mathrm{e}$ & $0.590 \mathrm{bc}$ & $0.175 \mathrm{~cd}$ & $10.4 \mathrm{ab}$ & $5.3 \mathrm{bcd}$ \\
\hline T6 & Water & $\mathrm{CK}$ & $22.4 \mathrm{c}$ & $10.07 \mathrm{c}$ & $0.680 \mathrm{~cd}$ & $0.300 \mathrm{c}$ & $1.64 \mathrm{c}$ & $0.94 \mathrm{c}$ & $0.600 \mathrm{~b}$ & $0.274 \mathrm{~b}$ & $10.5 \mathrm{ab}$ & $5.6 \mathrm{~b}$ \\
\hline $\mathrm{T} 7$ & CK & CK & $24.5 \mathrm{a}$ & $11.16 \mathrm{a}$ & $0.755 \mathrm{a}$ & $0.360 \mathrm{a}$ & $1.82 \mathrm{a}$ & $1.18 \mathrm{a}$ & $0.802 \mathrm{a}$ & $0.296 \mathrm{a}$ & $10.8 \mathrm{a}$ & $6.0 \mathrm{a}$ \\
\hline $\mathrm{T} 8$ & IAA & $\mathrm{CK}$ & $23.5 b$ & $10.79 b$ & $0.705 b$ & $0.350 \mathrm{~b}$ & $1.70 \mathrm{~b}$ & $1.05 b$ & $0.607 \mathrm{~b}$ & $0.280 \mathrm{~b}$ & $10.7 \mathrm{ab}$ & $5.6 \mathrm{~b}$ \\
\hline T9 & $\mathrm{CK}$ & IAA & $23.4 \mathrm{~b}$ & $8.49 \mathrm{~d}$ & $0.700 \mathrm{bc}$ & $0.275 \mathrm{~d}$ & $1.69 \mathrm{~b}$ & $0.89 \mathrm{~d}$ & $0.596 \mathrm{~b}$ & $0.182 \mathrm{c}$ & $10.7 \mathrm{ab}$ & $5.5 b$ \\
\hline
\end{tabular}

Means in each column followed by similar letter(s) are not significantly different at 5\% probability, using Duncan's Multiple Range Test 
جدول 9- مقايسه ميانگين خصوصيات دانه، عملكرد دانه و شاخص برداشت گندم در تيمارهاى محلولياشى اكسين و سيتو كينين

Table 6. Mean comparison of grain characteristics, grain yield and harvest index of wheat in auxin and cytokinin application treatments

\begin{tabular}{|c|c|c|c|c|c|c|c|c|c|c|}
\hline \multicolumn{3}{|c|}{$\begin{array}{c}\text { تيمارهاى محلولياشى } \\
\text { Growth regulator application treatments }\end{array}$} & \multirow{2}{*}{ 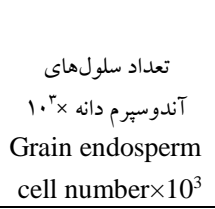 } & \multirow[b]{2}{*}{$\begin{array}{c}\text { سرعت ير شدن دانه } \\
\text { Grain filling rate } \\
\left(\text { mg.day }{ }^{-1}\right)\end{array}$} & \multirow[b]{2}{*}{$\begin{array}{c}\text { دوره مؤثر ير شدن دانه } \\
\text { Effective grain filling period } \\
\text { (day) }\end{array}$} & \multirow[b]{2}{*}{$\begin{array}{c}\text { وزن هزاردانه } \\
1000 \text { Grain weight } \\
\text { (g) }\end{array}$} & \multirow[b]{2}{*}{$\begin{array}{c}\text { قندهاى محلول دانه } \\
\text { Soluble sugars content } \\
\text { (mg.g } \text {. }^{-1} \text { DW) }\end{array}$} & \multirow[b]{2}{*}{$\begin{array}{c}\text { نشاسته دانه } \\
\text { Starch content } \\
\left(\mathrm{mg} \cdot \mathrm{g}^{-1} \mathrm{DW}\right) \\
\end{array}$} & \multirow[b]{2}{*}{$\begin{array}{c}\text { عملكرد دانه } \\
\text { Grain yield } \\
\left(\mathrm{kg}^{2} \mathrm{ha}^{-1}\right)\end{array}$} & \multirow[b]{2}{*}{$\begin{array}{c}\text { شاخص برداشت } \\
\text { Harvest index } \\
\text { (\%) }\end{array}$} \\
\hline $\mathrm{T}$ & 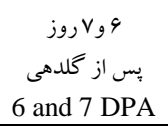 & 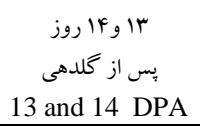 & & & & & & & & \\
\hline $\mathrm{T} 1$ & water & water & $235 d$ & $1.33 \mathrm{e}$ & $26.1 \mathrm{bc}$ & $34.8 \mathrm{~d}$ & $121 \mathrm{a}$ & $513 c$ & $5942 c$ & $38.9 d$ \\
\hline $\mathrm{T} 2$ & IAA & water & $277 \mathrm{c}$ & $1.22 \mathrm{f}$ & $29.0 \mathrm{a}$ & $35.5 \mathrm{~d}$ & $119 \mathrm{a}$ & $520 \mathrm{c}$ & $6039 c$ & $39.7 d$ \\
\hline $\mathrm{T} 3$ & water & IAA & $240 \mathrm{~d}$ & $1.51 \mathrm{~d}$ & $25.3 \mathrm{~cd}$ & $38.3 \mathrm{c}$ & $111 b c$ & $559 \mathrm{ab}$ & $6558 \mathrm{bc}$ & $43.0 \mathrm{c}$ \\
\hline $\mathrm{T} 4$ & IAA & IAA & $284 \mathrm{abc}$ & $1.55 \mathrm{~cd}$ & $27.1 \mathrm{~b}$ & $41.9 b$ & $109 \mathrm{c}$ & $569 a$ & $7143 \mathrm{ab}$ & $47.0 \mathrm{~b}$ \\
\hline T5 & CK & water & $279 b c$ & $1.18 \mathrm{f}$ & $30.0 \mathrm{a}$ & $35.4 \mathrm{~d}$ & $118 \mathrm{ab}$ & $528 \mathrm{bc}$ & $6041 c$ & $39.6 \mathrm{~d}$ \\
\hline T6 & water & $\mathrm{CK}$ & $242 \mathrm{~d}$ & $1.59 \mathrm{c}$ & $24.5 \mathrm{~d}$ & $38.9 \mathrm{c}$ & $108 \mathrm{c}$ & $576 \mathrm{a}$ & $6642 b c$ & $43.6 c$ \\
\hline $\mathrm{T} 7$ & $\mathrm{CK}$ & $\mathrm{CK}$ & $292 a$ & $1.79 \mathrm{a}$ & $26.3 b c$ & $46.1 \mathrm{a}$ & $107 \mathrm{c}$ & $580 \mathrm{a}$ & $7891 \mathrm{a}$ & $51.2 \mathrm{a}$ \\
\hline $\mathrm{T} 8$ & IAA & $\mathrm{CK}$ & $288 \mathrm{ab}$ & $1.71 \mathrm{~b}$ & $26.2 b c$ & $43.7 \mathrm{~b}$ & $107 \mathrm{c}$ & $582 \mathrm{a}$ & $7505 a$ & $48.7 b$ \\
\hline $\mathrm{T} 9$ & $\mathrm{CK}$ & IAA & $286 a b c$ & $1.56 \mathrm{~cd}$ & $27.5 \mathrm{~b}$ & $42.1 \mathrm{~b}$ & $108 \mathrm{c}$ & $574 a$ & $7155 \mathrm{ab}$ & $46.9 \mathrm{~b}$ \\
\hline
\end{tabular}

Means in each column followed by similar letter(s) are not significantly different at 5\% probability, using Duncan's Multiple Range Test 
بوده است كه اين موضوع باعث افزايش وزن هزار دانسه و در نتيجه افزيش عملكرد دانه و شاخص برداشت شده

است.

\section{نتيجه كيرى}

بر اساس نتـايج ايسن آزمـايش بـه نظـر مـىرســ كـه

افـزايش معنسى دار تعـداد ســبلههـا در مترمربـع در اثـر

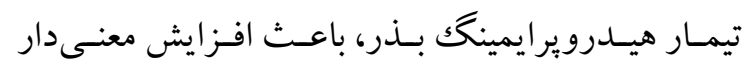

عملكرد دانسه نسـبت بـه شـاهد (بـذرهاى بــدون يـرايم)

كرديد. محلولياشسى اكسين و سـيتو كينين روى روابـ

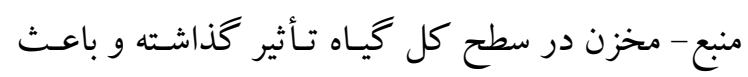

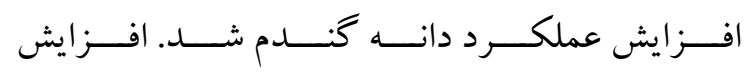

سطح سـيتو كينين و اكسـين در مـدت نمـو دانه، باعـث

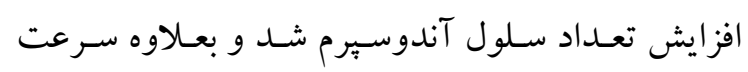

فتوسـنتز و يايسدارى آن در واحـــ زمـان افـزايش يافـت.

اين تـأثير در محلولباشسى سـيتو كينين در هـر دو زمـان

(يكك و دو هفته بس از كلدهى) بيشتر بـود كـه احتمـالا

مى تو اند به دليـل اثـرات ويـزّه شـناخته شـــه ايسن تنظيم

كننده رشـــ در تقسـيمات سـلولى و بـه تـأخير انـداختن

$$
\text { ييرى كياه باشد. }
$$

$$
\begin{aligned}
& \text { بيشتر از سال اول بود كـه احتمـالا بـه دليـل بيشـتر بـودن } \\
& \text { تعداد سنبلهها در متر مربع در اين سال بوده اسـت. نتـايج }
\end{aligned}
$$

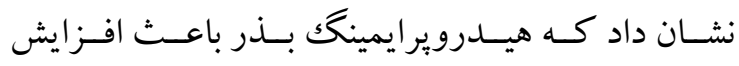

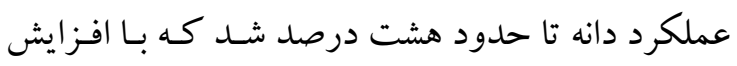

$$
\begin{aligned}
& \text { تعداد سنبله در متر مربع در اثـر هيـدروير ايمينگك مـرتبط }
\end{aligned}
$$

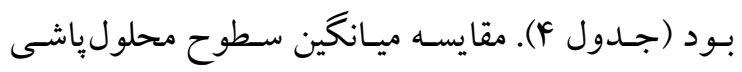

$$
\begin{aligned}
& \text { اكسـين و سـيتو كينين نشـان داد كــه عملكــــد دانسه در } \\
& \text { محلولياشى هايى كه در هر دو مرحله (يـك و دو هفتـه } \\
& \text { يس از كلـدهى)، انجـام شـده بـود، تفـاوت معنى دارى } \\
& \text { نداشته و بيشـتر از سـاير تيمارهـا بـود. عملكـرد دانـه در } \\
& \text { محلول ياشى سيتو كينين - سيتو كينين، YF/V درصد بيشـتر } \\
& \text { از شاهد بود (جدول 9). مقايسه ميانگينها نشـان داد كـه } \\
& \text { بيشـترين شـاخص برداشـت مربـوط بـه محلـولياشـى } \\
& \text { سيتو كينين - سيتو كينين بود (جدول 9). در اين تيمار، در }
\end{aligned}
$$

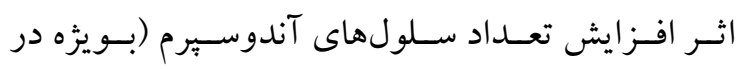

$$
\begin{aligned}
& \text { محلول باشى سيتو كينين در هفته اول يـس از كلـدهى) و و } \\
& \text { نيز در اثر افزايش ميزان و سرعت دريافت مـواد يـرورده } \\
& \text { (بويزه در محلولياشى سـيتو كينين در هفتـه دوم بـس از }
\end{aligned}
$$

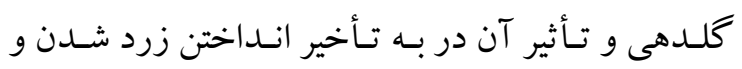

$$
\begin{aligned}
& \text { كاهش فتوسنتز بر ك ها)، ظرفيت دانه بـراى نمـو، بيشـتر }
\end{aligned}
$$

\section{References}

\section{منابع مورد استفاده}

Aboutalebian, M. A., F. Sharifzadeh, M. R. Jahansouz, A. Ahmadi, and M. R. Naghavi. 2008. The Effect of seed priming on germination, stand sstablishment and yield of wheat (Triticum aestivum L.) cultivars in three different climates of Iran. Iran. J. Field Crops Sci. 39(1): 145-154. (In Persian with English abstract).

Abdolrahmani, B., K. Ghassemi-Golezani, M. Valizadeh, V. Feizi-Asl, and A. R. Tvakoli. 2011. Effects of seed priming on seed vigor and grain yield of barley (Hordeum vulgare L. cv. Abidar) in rainfed conditions. Seed Plant Prod. J. 11(4): 337-352 (In Persian with English abstract).

Abdolrahmani, B., K. Ghassemi-Golezani, M. Valizadeh and V. FeiziAsl. 2007. Seed priming and seedling establishment of barley (Hordeum voulgare). J. Food Agric. Environ. 5: 179-184.

Amal, M., E. Shraiy, and A. M. Hegazi. 2009. Effect of acetylsalicylic acid, indole-3-butyric acid and gibberellic acid on plant growth and yield of pea (Pisum sativum L.). J. Basic Appl. Sci. 3: 3514-3523.

Ashraf, M. Y., N. Azhar and M. Hussain. 2006. Indole acetic acid (IAA) induced changes in growth, relative water contents and gas exchange attributes of barley (Hordeum vulgare L.) grown under water stress 


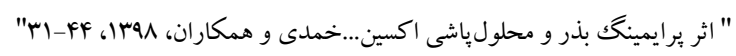

conditions. Plant Growth Regul. 50:85-90.

Arnon, D. I. 1949. Copper enzymes in isolated chloroplasts: polyphenol-oxidase in Beta vulgaris. Plant Physiol. 24: $1-15$.

Bajguz, A. and A. Piotrowska. 2009. Conjugates of auxin and cytokinin. Phytochemistry. 70: 957-969

Bhatia, S. and R. Singh. 2002. Phytohormone-mediated transformation of sugars to starch in relation to the activities of amylases, sucrose-metabolising enzymes in sorghum grain. Plant Growth Regul. 00: 1-8.

Bradford, M. M. 1976. A rapid and sensitive method for the quantification of microgram quantities of protein utilizing the principle of protein dye bonding. Analytical Biochem. 72: 248-254.

Brenner, M. L. and N. Cheikh. 1995. The role of phytohormones in photosynthate partitioning and seed filling. In: Davies P.J. (Ed.), Plant Hormones. Kluwer Academic Press, Dordrecht, Boston, London, pp. 649-670.

Davies, P. J. 1987. The Plant Hormones: Their Nature, Occurrence and Functions. In: P. J. Davies, P. J. (Ed.), Plant Hormones and Their Role in Plant Growth and Development. Martinus Nijhoff Publishers, The Netherlands, pp 1-11.

Dua, I. S. and S. N. Bhardwaj. 1979. Levels of endogenous growth regulators in wheat during early stages of grain setting and development. Indian J. Agric. Sci. 55: 622-627.

Dubios, M. K. A. Gills, J. K. Hamilton, P. A. Rebers and F. Smith. 1956. Colorimetric method for determination of sugars and related substances. Annals Chem. 28(3): 350-356.

Ellis, R. H. 1992. Seed and seedling vigour in relation to crop growth and yield. Plant Growth Regul. 11: 249255.

Farooq, M., S. M. A. Basra, H. Rehman and B. A. Saleem. 2008. Seed priming enhances the performance of late sown wheat (Triticum aestivum L.) by improving chilling. J. Agron. Crop Sci. 194: 55-60.

Ghorbani Javid, M., A. Soroushzadeh, S. A. M. Modarres Sanavy, I. Allahdadi and F. Moradi. 2011. Effects of the exogenous application of auxin and cytokinin on carbohydrate accumulation in grains of rice under salt stress. Plant Growth Regul. 65:305-313.

Giri, G. S. and W. F. Schillinger. 2003. Seed priming winter wheat for germination, emergence and yield. Crop Sci. 43: 2135-2141.

Gupta, N. K. S. Gupta, D. S. Shukla and P. S. Deshmukh. 2003. Differential responses of BA injection on yield and specific grain growth in contrasting genotypes of wheat (Triticum aestivum L.). Plant Growth Regul. 40: 201-205.

Hakoomat, A., I. Nadeem, S. Naeem, A. Shakeel and M. Athar. 2013. Seed priming improves irrigation water use efficiency, yield and yield components of late-sown wheat under limited water conditions. Turk. J. Agric. Forest. 37: 534-544.

Harris, D., A. K. Pathan, P. Gothkar, A. Joshi, W. Chivasa and P. Nyamudeza. 2001. On-farm seed 


$$
\text { "مجله علوم زراعى ايران"، جلد بيست و يكم، شماره ا، بهار 1"11 }
$$

priming: using participatory methods to revive and refine a key technology. Agric. Sys. 69: 151-164.

Hashemi Dezfouli, A. And A. S. Marashi. 1995. Changes in photosynthetic material at flowering time and its effect on grain growth, yield and yield components of wheat. J. Agric. Sci. Technol. 9: 32-16. (In Persian with English abstract).

Havlova, M., P. I. Dobrev, V. Motyka, H. Storchova, J. Libus, J. Dobra', J. Malbeck, H. Gaudinova and R. Vankova. 2008. The role of cytokinins in responses to water deficit in tobacco plants over-expressing trans-zeatin O-glucosyltransferase gene under 35S or SAG12 promoters. Plant Cell Environ. 31: 341-353.

Herzog, H. 1982. Relation of source and sink during grain filling period in wheat and some aspects of the regulation. Physiol. Plant. 56: 155-160.

Khan, M. B., M. Gurchani, M. Hussain and K. Mahmood. 2010. Wheat seed invigoration by pre-sowing chilling treatments. Pak. J. Bot. 42: 1561-1566.

Liang, J., J. Zhang and X. Cao. 2001. Grain sink strength may be related to the poor grain filling of indicajaponica rice (Oryza sativa) hybrids. Physiologia Plantarum 112: 470-477.

McDonald, M.B. 2000. Seed Priming. In: Black, M. and J. D. Bewley (Eds.), Seed Technology and its Biological Basis. Sheffield Academic Press, Sheffield, UK. pp: 287-325.

Peleg, Z., M. Reguera, E. Tumimbang, H. Walia and E. Blumwald. 2011. Cytokinin-mediated source /sink modifications improve drought tolerance and increase grain yield in rice under water-stress. Plant Biotechnol. J. 8: 1-12.

Rehman, H., S. M. A. Basra and M. Farooq. 2011. Field appraisal of seed priming to improve the growth, yield, and quality of direct seeded rice. Turk. J. Agric. Forest. 35: 357-365.

Saeidi, M., F. Moradi, A. Ahmadi, K. Poostini and G. Najafian. 2006. Effect of exogenous application of $\mathrm{ABA}$ and $\mathrm{CK}$ at different stages of grain development on some physiological aspects of source and sink relationship in two bread wheat cultivars. Iran J. Crop Sci. 8( 3): 268-282. (In Persian with English abstract).

Walker, D.J., P. Romero, A. de Hoyos and E. Correal .2008. Seasonal changes in cold tolerance, water relations and accumulation of cations and compatible solutes in Atriplex halimus L. Environ. Exp. Bot. 64: $217-224$.

Wingler, A., A. Scahewen, C. L. Richard, J. Peter and W. L. Paul-Quic. 1998. Regulation of leaf senescence by cytokinin, sugars and light. Plant Physiol. 116: 329-335.

Xu, G., J. Zhang, HM. Lam, Z. Wang and J. Yang. 2007. Hormonal changes are related to the poor grain filling in the inferior spikelets of rice cultivated under non-flooded and mulched condition. Field Crops Res. 101: 53-61.

Yang, J. C., J. Zhang, Z. Wang and Q. Zhu. 2003. Hormones in the grains in relation to sink strength and post anthesis development of spikelets in rice. Plant Growth Regul. 41: 185-195. 


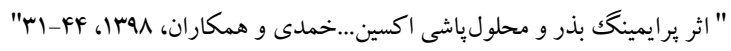

\title{
Effect of seed priming and application of cytokinin and auxin on growth and grain yield of wheat (Triticum aestivum $\mathbf{L}$.) under Ahvaz climatic conditions
}

\author{
N. Khamdi ${ }^{1}$, M. Nabipour ${ }^{2}$, H. Roshanfekr ${ }^{3}$, and A. Rahnama ${ }^{4}$
}

\begin{abstract}
N. Khamdi, M. Nabipour, H. Roshanfekr, and A. Rahnama. 2019. Effect of seed priming and application of cytokinin and auxin on growth and grain yield of wheat (Triticum aestivum L.) under Ahavz climatic conditions. Iranian Journal of Crop Sciences. 21(1): 31-44(In Persian).

To evaluate the effect of seed priming and application of cytokinin and auxin on grain yield wheat cv. Chamran, an experiment was carried out in Faculty of Agriculture, Shahid Chamran University of Ahvaz, Iran, in 2015-16 and 2016-17 growing seasons. This experiment was carried out as factorial arrangement in randomized complete block design with three replications. Experiment was carried out in a factorial arrangement based on randomized complete block design with three replications. Treatments included seed priming (hydropriming and control) and plant growth regulators application (nine cytokinin and auxin application levels at one and two weeks after anthesis). The results showed that hydropriming significantly increased grain yield by about $8 \%$ in comparison with control (7030 and $6507 \mathrm{~kg} \cdot \mathrm{ha}^{-1}$, respectively). Application of cytokinin and auxin hormones had positive effect on photosynthesis and soluble proteins of flag leaf. In addition, number of endosperm cells was also increased by application of growth regulators. The highest effect on increasing source strength was observed in application of cytokinin in both times of foliar application. Grain filling rate was also significantly highest, about $1.79 \mathrm{mg}_{\text {grain }}{ }^{-1}$ day $^{-1}$, in cytokinin-cytokinin foliar application, followed by auxincytokinin. Grain yield in cytokinin-cytokinin $\left(7891 \mathrm{~kg} \cdot \mathrm{ha}^{-1}\right)$ increased by $24.7 \%$ in comparison with control. Interaction effect of seed priming $\times$ plant growth regulator application was not significant for any traits. Results of this experiment showed that seed priming increased number of spike per.m ${ }^{-2}$. Foliar application of auxin and cytokinin also may increase grain yield of wheat through enhancing of source and sink strength.
\end{abstract}

Key words: Endosperm cells, Grain filling, Hydropriming, Plant growth regulators and Wheat

\footnotetext{
Received: April, $2018 \quad$ Accepted: February, 2019

1. PhD Student, Shahid Chamran University of Ahvaz, Ahvaz, Iran

2. Professor, Shahid Chamran University of Ahvaz, Ahvaz, Iran (Corresponding author)

(Email: m.nabipour@scu.ac.ir)

3. Associate Prof., Shahid Chamran University of Ahvaz, Ahvaz, Iran
} 
"مجله علوم زراعى ايران"، جلد بيست و يكم، شماره ا، بهار شوبا

4. Associate Prof., Shahid Chamran University of Ahvaz, Ahvaz, Iran 